\title{
The Role of the Archeological Heritage Sites in the Process of Urban Regeneration of UNESCO's Cities-Boka Bay Case Study
}

\author{
Slađana Lazarević $1,2, * \mathbb{D}$, Dražen Arbutina ${ }^{3}$ and Svetislav G. Popović ${ }^{2}$ \\ 1 UNDP Montenegro, 81000 Podgorica, Montenegro \\ 2 Faculty of Architecture, University of Montenegro, 81000 Podgorica, Montenegro; svetislav@ucg.ac.me \\ 3 Department of Civil Engineering, Zagreb University of Applied Sciences, Vrbik 8, 10000 Zagreb, Croatia; \\ darbutina@tvz.hr \\ * Correspondence: sladjana.lazarevic@undp.org or sladjanal@ucg.ac.me or sladja.lazarevic@gmail.com; \\ Tel.: +382-67-661-386
}

check for updates

Citation: Lazarević, S.; Arbutina, D.; Popović, S.G. The Role of the Archeological Heritage Sites in the Process of Urban Regeneration of UNESCO's Cities-Boka Bay Case Study. Sustainability 2022, 14, 1566. https://doi.org/10.3390/su14031566 Academic Editors: Andrea Zerboni, Filippo Brandolini, Francesco Carrer and Guido S. Mariani

Received: 1 January 2022

Accepted: 23 January 2022

Published: 28 January 2022

Publisher's Note: MDPI stays neutral with regard to jurisdictional claims in published maps and institutional affiliations.

Copyright: (C) 2022 by the authors. Licensee MDPI, Basel, Switzerland. This article is an open access article distributed under the terms and conditions of the Creative Commons Attribution (CC BY) license (https:// creativecommons.org/licenses/by/ $4.0 /)$.

\begin{abstract}
The role of the archeological and cultural heritage sites in the process of urban regeneration in UNESCO's protected areas becomes more and more important for the natural and cultural heritage protection in the touristic cities with urban expansion. However, there is no clear methodological approach for the inclusion of these important natural and cultural heritage sites in the process of urban regeneration of the cities. The purpose of this study is to analyze how two contemporary urban planning tools, sustainable urban mobility plans and heritage impact assessments, contribute to the protection and sustainable use of archeological sites. The methodology that is used in this study is dual, theoretical, through literature review, and empirical, through the appliance of the case study method and expert observation and mapping of the most valuable archeological sites in Boka Bay. The results of this study show that practical usage of the two proposed tools in the process of urban regeneration could help in cultural and natural heritage protection and their inclusion as drivers of sustainable urban planning and cultural heritage management. The results of the study confirm the authors' hypothesis that the role of the archeological sites in the process of urban regeneration is evident in the touristic cities in the coastal area of Montenegro, concluding that urban mobility principles and heritage impact assessment studies must be considered in the process of urban regeneration while at the same time cultural (archeological) heritage management is an integral part of this process.
\end{abstract}

Keywords: cultural heritage management; archeological heritage management; urban regeneration; sustainable urban mobility; UNESCO's cities; Boka Bay; archeological sites; cultural heritage preservation

\section{Introduction}

Decay of cultural heritage; poor archeological research of valuable sites; inadequate restoration, protection, and valorization, and also the lack of activities focused on adequate conservation of archeological sites and often the lack of simple presentation of cultural assets are the problems of today's architectural and urbanistic practice. Archeologists have been aware since the 1960s that archeological sites are rapidly disappearing and that only a small part of them can be documented through protective archeological research (excavations).

The preservation of archeological sites needs a different approach that requires communicating with the "outside world," influencing political and socio-economic decisionmaking processes, and gaining public support. This process includes a gradual replacement of the existing model of protection with a more dynamic concept of archeological management heritage within the spatial planning system. This process began in the United States in the 1970s and in the 1980s in a number of European countries [1] (p. 284), [2]. 
The principle of integrated protection linking heritage protection with the spatial planning process has previously been emphasized for architectural heritage in European countries (Resolution (68) 12 on the active maintenance of monuments, groups, and sites of historical and artistic significance in the context of regional planning in 1968, Amsterdam Declaration, 1975. (European Charter for Architectural Heritage 1975)). In the Western Balkans, Croatia has a long tradition of thinking about the protection of cultural, historical, and archeological heritage in the context of urban and spatial planning, which began in the 1960s and anticipated many principles of protection that were later accepted internationally. Archeological heritage management is an important component of the sustainable heritage-based method of the urban regeneration process. The heritage-based method of urban regeneration is a research method presented by Amado and Rodrigues, from Portugal, for the case study of Luanda (Angola) [3].

The process of urban regeneration by itself cannot be analyzed or applied without including heritage in the process of renewal or rehabilitation of cities, while cities that rely on tourism as the main economic branch cannot develop themselves without including cultural heritage and archeological sites in their tourist offer and thus in the preservation and promotion of the cultural identity of the country as an extremely important value. Therefore, it is necessary to examine the role of archeological sites as drivers of economic development and social cohesion of the country to which they belong.

Within the official protection of the world heritage sites starting from the 1970s, far more attention was given to cultural and natural heritage preservation, especially with the adoption of the European Charter on Architectural Heritage in 1975.

The subject of this paper is Boka Bay in Montenegro. Five towns of Boka Bay, presented in this paper, with its outstanding historical and cultural heritage, are located on the coast, by the sea: Kotor, Tivat, Perast, Risan, and Herceg Novi. Being included in the World Heritage List of UNESCO, Kotor's special significance is reflected in its own cultural heritage. Kotor is located on the route of the Adriatic highway (which goes directly through urban areas and along the walls of the Old City, one of the most-visited tourist attractions in Montenegro), while it is connected with other coastal and continental areas by the Vrmac tunnel [4]. The complex development problems of modern cities demand careful consideration and the development of innovative approaches, especially in protected areas with a high number of archeological sites not incorporated in tourism's offers nor in clear planning strategies.

This paper analyzes the archeological sites in the territory of Boka Bay and their role in the process of urban regeneration of the cities that belong to this bay through the theoretical and empirical methods of research. The theoretical research methods include literature review and the review of cartographic and archeological research conducted hitherto. Through the method of the case study of Boka Bay, it is explained how the usage of the two planning tools as a model for better integral protection of the archeological heritage sites could contribute to the urban regeneration of these cities. These two planning tools are related to the sustainable urban mobility theoretical concept and heritage impact assessment.

What is a particularly important segment of integrated spatial protection is the recognition of a famous place and a protected environment. The Rulebook defines that a significant place is a space where a significant event took place or a space that is recognizable by a prominent person [5]. A protected environment is an area around the immovable cultural property that is of immediate importance for its existence, protection, use, appearance, preservation, and research, as well as for its historical context, traditional ambiance, and visual accessibility [6]. Therefore, it is crucial that previous research is done focusing on quality and provides a prerequisite for the future integrated protection of the entire urban and rural heritage. 


\subsection{Archeological Sites as a Resource in Spatial and Urban Planning}

The goals of spatial planning are subordinated to the time in which they are created. So, in this regard, the urban solution is more than necessary and logical to seek in respect of nature and architectural heritage, to the extent appropriate to the selected space and content. It is basically recognizing the archeological heritage as a potential for spatial and sustainable development through its protection, promotion, and use that contributes to the preservation of the identity of the community; modern creativity; and overall social, economic, and spatial development.

The European Cultural Convention, signed in Paris in 1954 [7], emphasized the importance of preserving the common European cultural heritage. The term "cultural heritage" was first used in 1969, while in the 1970s, the term cultural heritage was expanded to include all cultural elements of the environment that people valued and wanted to preserve for future generations.

The need for visual impact studies on the cultural property is often overlooked, as is the heritage impact assessment (HIA), a heritage impact study. That is why the Florence Convention [8] offered a solution for the inclusion of cultural and natural values in the mechanisms of sustainable spatial planning.

\subsubsection{Historical Development of the Idea of Archeological Heritage Management}

Since the 1960s, a number of changes have taken place (outside and inside archeology) that have influenced the understanding of the protection of the archeological heritage. The environmental movement has begun, and the fact that the world's natural and cultural resources are in danger is being recognized. Archeological science itself has undergone significant changes, with the development of new archeology (procedural archeology) in the United States, which places the main emphasis on archeological theory and which has been described in the 1970s as the "loss of innocence" in archeology. The 1960s marked a turning point for archeology because dissatisfaction with the classification-historical approach led to the creation of the new archeology-procedural archeology. Her proponents argued that the past should be interpreted in addition to descriptions. To achieve this, procedural archeologists have shifted from a historical approach to a scientific one. The postmodern approach to archeology in the 1980s and the 1990s led to the development of post-procedural and interpretive archeology. Proponents of this approach argue that objectivity in research is not possible and that there is no one way to conclude. The different perspectives of certain social groups and the fact that not everyone experiences the past in the same way are emphasized [9] (p. 50).

The consequence of these changes is the emergence of the concept of management of archeological heritage, or "resources." Archeological monuments, both movable and immovable, are no longer primarily viewed as objects of research but as cultural resources that can be used in the present and the future.

In the early 1990s, two international documents were adopted, the Charter on the Protection and Management of Archeological Heritage (1990) and the European Convention on the Protection of the Archeological Heritage (revised) (1992), which set out modern international views and standards of archeological heritage management, where the need for protection and preservation of archeological heritage in situ and avoidance of archeological excavations, which are replaced by non-destructive research methods, is especially emphasized.

The field of archeological heritage management is still an area of scientific research in which archeology goes in a direction significantly different from its traditional field/subject of research: the role of archeology in modern society, the theory of archeological heritage management, the interpretation of a large amount of collected data (obtained by protective research), concepts in relation to other disciplines, the quality of archeological research, archeological ethics, criteria, methods of evaluation of archeological heritage, protection of un-excavated sites, technical tools, the possibility of reconstruction, the relationship between indigenous communities and archeology, archeology and socioeconomic 
development, factors endangering archeological heritage change to archeological heritage, etc. [10-13].

1.1.2. The Process of Managing the Archeological Heritage, Its Presentation, and Its Interpretation In Situ

The modern system of archeological heritage management implies two levels. The first refers to the management of the total archeological heritage (resources in a territory), while the second refers to immovable archeological cultural goods (sites for which a decision has been made to preserve them in situ). Both levels of government, apart from archeologists and conservators, include urban planners and spatial planners as actors [10,12].

Although a set of laws in the field of cultural and archeological heritage protection was adopted in Montenegro that regulated this area, including modern principles of protection and international conventions in the field of heritage protection, in practice in the last 20 years, many sites have been devastated by negligence or inadequate interventions. The Law on Protection of Cultural Heritage from 2010 prescribed the obligation to adopt a study for the protection of cultural heritage for each scope before elaboration and adoption of a planning document that will clearly define the status, measures, and protection regime, with the aim of proper treatment of cultural heritage. The issue of application of laws and measures of modern protection and revitalization of architectural heritage remains open. The UNESCO Convention for the Protection of the Natural and Cultural Heritage (1972) is the only international instrument for the recognition and protection of the cultural and natural heritage. In 1992, this convention became the first legal instrument for the protection of the cultural landscape [14].

Although the first archeological excavations of ancient heritage sites began in the second half of the 19th century, in the territory of today's Boka Bay, excavations have been decreased to only a few sites, such as (1) ancient roads, (2) Risan (Rhizonium-Ricinus), (3) Perast, (4) St. Stephen, (5) Lipci, and (6) Carine [15-19].

The following authors wrote the most about the first archeological research and anthropological urban development: Garašanin [20], Mijović [21-23], Pušić [16,17], Bošković [24], Jovanović [25], Čubrović [26], Lisavac [27], Mijušković [15], Ilijanić [28-30], and Lalošević [31-33]. In this paper, in the Results section, more than 80 archeological sites are mapped using the method of literature review and desk and site experts' observations.

In the presented model of the process of archeological heritage management, all steps except selection belong to the field of archeology. The choice of which site to preserve in situ, excavate, monitor during removal, or completely ignore does not belong to the field of archeology but is in fact a political decision. This decision is made by the governmentstate, and it primarily depends on archeological research that supports and justifies a particular decision [1]. Inventory, primary valuation, and selection represent the first level of archeological heritage management. The system of archeological heritage management is determined by the administrative and legal framework of each country in which it is implemented [34].

Archeological heritage management generally includes public administration, laws, professional and scientific principles on which the inventory is based, field survey (reconnaissance), excavation, research, research documentation, evaluation (valorization), maintenance, conservation, legal protection, possibility reconstructions, interpretation, presentation, public access, use, improvement of archeological heritage, and education of experts and the public. The process of managing archeological heritage/resources includes several basic stages: (1) inventory, (2) primary valorization, (3) selection, i.e., the decision on in situ preservation or protective excavation, and (4) interpretation and synthesis. It is important to emphasize the feedback between archeological research and the management process [35].

The main goal of developing an archeological site sustainable management plan is to ensure the preservation of all its values and cultural significance, and not to meet the needs 
of tourists, archeologists, or entrepreneurs, though their requirements may be taken into account to some extent.

Since it is not realistic to preserve all archeological remains and sites, it is necessary to select those that will be preserved in situ (as archeological heritage) and those that will be designated only for documentation and excavation (protective archeological research).

The second stage of management in the analytical and planning-project stage includes the need for presentation and interpretation of the archeological heritage for which the decision on in situ preservation was made [36]. Except in exceptional cases, all archeological sites should be open to the public. The opening of the site to the public must be accompanied by a program of interpretation that will make the exhibited archeological remains understandable [37]. Interpretation thus becomes one of the key elements in the process of protecting and opening the site to the public. Archeological findings open to the public are often better protected than sites that have not become tourist sites. The presentation of the archeological heritage of the institute, however, can have positive and negative consequences (not including a number of natural causes of decay) for its protection.

This second stage is key for the urban regeneration process as a tool for sustainable urban planning.

\subsection{Urban Regeneration as a Spatial Planning Principle in the Protection of the Built Environment and Historic Urban Landscape}

The challenge that urban regeneration has to face always is the preservation of the identity and memory of places as well as the close relationship between the history of human activities and its spatialization. The functional requirements of the timing of interventions and their needs fall within a framework of sustainability and make it necessary for heritage to be safeguarded so that it can serve as a reference for future generations. The urban regeneration process may acquire different modes of implementation.

Considering that heritage is the fundamental issue in all of the three main pillars of sustainability, the cultural and identity values were examined in even greater depth. In the literature review process, articles, books, and other sources have been divided between those that provide "scientific"-research-based methodologies, whether empirical, using quantitative and/or qualitative surveys, and those that are illustrative, with descriptive reference to practical case studies [3].

According to Begovic, "Urban reconstruction is a process of changing the purpose and intensity of the use of city land [...] If urban reconstruction affects entire zones of the city that are not prosperous, ie. zones affected by degradation, then we are talking about urban regeneration" [38] (p. 348). According to Moughtin, "Urban regeneration is a very risky business for all those involved in it. Successful regeneration requires input from local communities, developers, funders, funds, the public sector in all activities (working on the physical, economic, and social improvement of urban space) and collaboration by various professions related to urban space" [39] (p. 17). The broadest definitions of the notion of urban regeneration (in relation to the notion of urban reconstruction) in the domestic context are given by Vaništa-Lazarević and Bazik: "[P]ublic spaces and the wider city. It implies the participation of various aspects of reconstruction in that procedure. Here we mean social change, economic advancement and more. It indicates one degree in advance." [40] (p. 58) and "Urban regeneration is a complex process that includes issues of financing, management, partnership and participation in order to achieve environmental, economic and social goals according to the principles of sustainable development, i.e., quality of life for today and for future generations" [41] (p. 259).

It is of great importance to understand the way heritage has been introduced in the evolution process of the cities and to understand different aspects of this evolution process. From the economical pillar aspect of sustainability, one of these evolution processes is the integration of cultural heritage and landscape integration but also the consideration of the energy efficiency aspects of the urban regeneration processes [42]. 
With the progress of society, the rapid urban growth associated with the intensive use of land, and the inability to guarantee adaptation to the constant and continuous change in its necessities, it becomes fundamental to promote new design strategies and approaches in order to transform today's city [43].

The global context related to spatial planning has changed with the adoption of the UN 2030 Agenda for Sustainable Development (2015) [44] and the UN New Urban Agenda (2016) [45].

A number of other internationally important documents recognize the role of heritage in sustainable development or in the way to have significant implications for urban heritage management, including Agenda 2030 (2015), the Sendai Framework for Disaster Risk Reduction (2015), the United Nations Framework Convention on Climate Change (UNFCCC), the Paris Agreement (2015), and the UNESCO SIDS Action Plan (2016). Several member states have recognized the synergies between the recommendations and sustainable urban development [46].

Cultural heritage plays an important role in the process of strategic and integral planning and protection of space because it can be the main driver of sustainable socioeconomic and cultural development. Theories of sustainable development and urban regeneration are now recognized in the New Urban Agenda as an instrument for the implementation and localization of Goal 11, Sustainable Cities and Communities, of the Agenda of Sustainable Development.

Current discussions on urban sustainability tend to focus on technical issues, such as emissions, energy consumption, and waste management, or on the economic aspects of urban regeneration and growth. However, the impact of archeological and architectural heritage on sustainable urban development, as well as on the social well-being of different groups of people, is increasingly recognized. Although many discussions are related to the role of archeological and architectural heritage in sustainable development, they are developed mostly only on a theoretical level.

"Sustainable mobility is the ability to meet society's desires and needs to move freely, gain access, communicate, trade and establish relationships without sacrificing other essential human or ecological values, today or in the future" [47].

The geographical scope of the polycentric sustainable urban mobility plan (PolySUMP) in Montenegro includes the area of Boka Bay and the Old Royal Capital of Cetinje, which covers an area of 1,526 km². The area of Boka Bay, from Herceg Novi to Kotor, also includes the towns of Risan, Perast, Dobrota, and Prcanj. The length of the bay surrounded by the Dinaric Alps (on the west by Mountain Orjen and on the east by Mountain Lovcen), including the existing traffic lane, is $28 \mathrm{~km}$. The longest part of the bay is the Strait of Verige, with a total length of $2.3 \mathrm{~km}$ and $340 \mathrm{~m}$ in width. The total population of the examined area is 84,153 inhabitants. Taking into account these data, as well as the fact that this geographical area has four different urban centers, it can be considered as a smaller region for the development of a Poly-SUMP (Figure 1).

The Poly-SUMP plan is based on a new EC methodology for the development of Poly-SUMPs that takes into account the polycentric characteristics of a region and its specific transport needs. The analyzed Poly-SUMP should facilitate the development of a more accessible, safer, cleaner, greener, and more reliable transportation system in the area, taking into account not only the specific characteristics of the region, such as the significant seasonal variations in traffic, due to its tourist attractions but also the capacity limitations of the existing transport system and could be considered as an important tool for the urban regeneration of this region. A Poly-SUMP is a tool for a new planning approach creating sustainable urban mobility plans (SUMPs) for a polycentric region and taking into account the polycentrism of the regional profile of Boka Bay. That is a reason why for this particular case in the process of urban regeneration, a Poly-SUMP approach should be used instead of a SUMP methodological approach. 


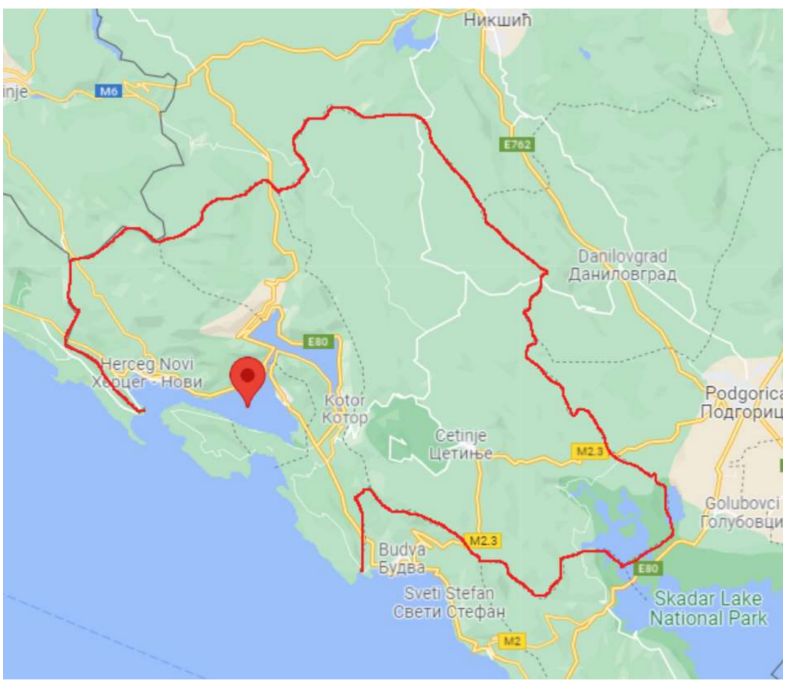

(a)

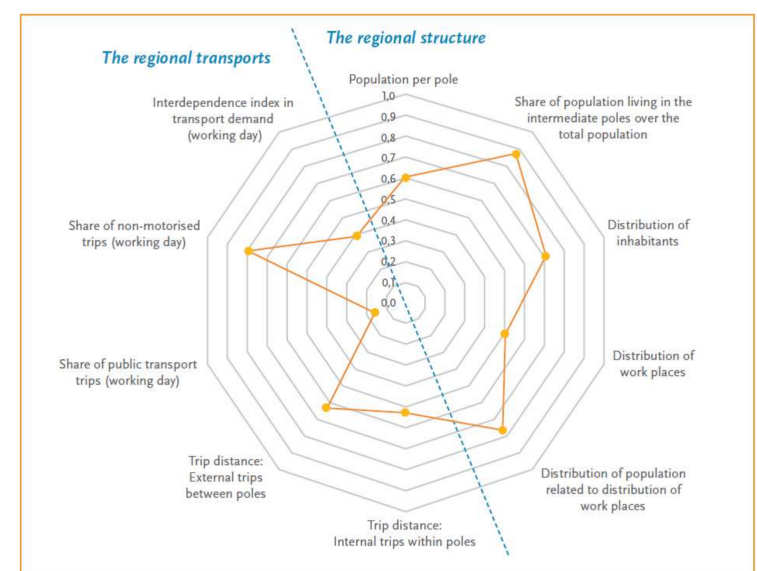

(b)

Figure 1. The Boka Bay area and the Old Royal Capital of Cetinje; (a) SUMP BokaCet (Google maps) and the regional profile of polycentrism; (b) the polycentric profile tool Poly-SUMP (http: //www.polysump.eu/tool/analysis, accessed on 15 December 2021).

\section{Materials and Methods}

This paper uses a dual-methodological research approach-theoretical, through literature review, and empirical, through the appliance of the case study method and expert observation and mapping of the most valuable archeological sites in Boka Bay. The results of this study show that practical usage of the two proposed tools in the process of urban regeneration could contribute to cultural and natural heritage protection and their inclusion in urban planning as drivers of a sustainable and healthier environment. The results are presented in Section 3, while the discussion on the results and the conclusion and open questions, along with the main funding of this study, are presented in Section 4.

To better understand the complexity of the multidisciplinary approach in this study, a methodological approach is presented in the scheme (Figure 2) explaining the connection between the two used planning methodological tools in the process of the urban regeneration of Boka Bay's cities in relation with archeological heritage management.

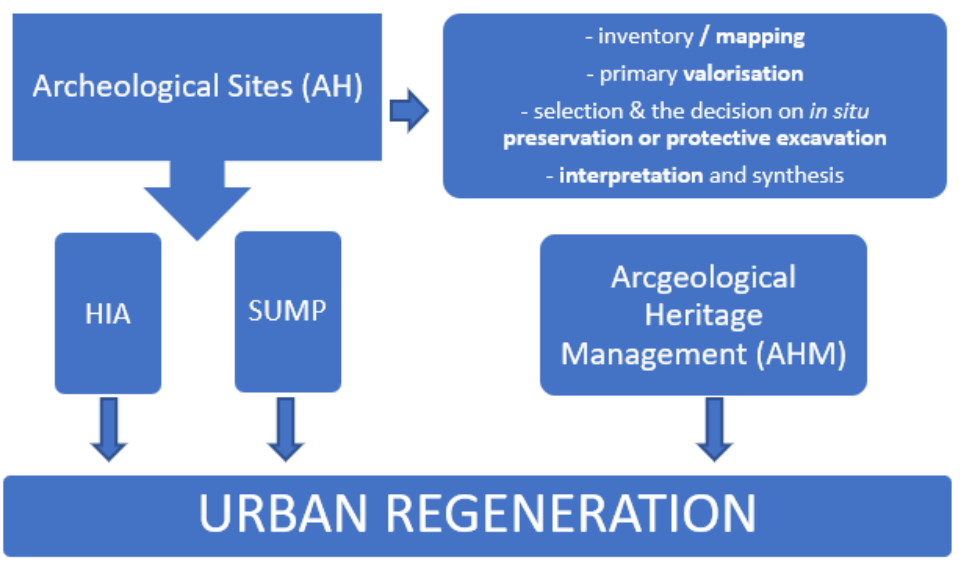

Figure 2. A conceptual scheme for the paper's methodological approach and the archeological heritage management methodology (prepared by the authors of this paper according to Willems).

The methodological approach is based on a review of a heritage-based method for urban regeneration, with a combination of the case study method, which includes two additional planning tools that could be used in the spatial planning process, for a better 
understanding of the environment issues, protection, and management of the archeological heritage sites.

To better present the aim of introducing the Poly-SUMP tool in the urban regeneration process, the methodology of the development of polycentric sustainable urban mobility plans is explained in detail hereafter.

Sustainable urban mobility plans (SUMP) [48] are strategic plans that build on existing practices in planning and take into account the integrated, participatory, and evaluation principle to meet the needs of the inhabitants of the towns for mobility and ensure a better quality of life in cities and their surroundings. These kinds of plans are developed mostly for urban areas and communities characterized by monocentrism, i.e., the concentration of human activities in one area. Polycentric sustainable urban mobility plans (Poly-SUMP) [49] are developed with the same objectives. However, unlike SUMPs, these are targeted at areas characterized by a dispersed distribution of activities, i.e., areas (regions) that include several urban centers that have a population between 5000 and 200,000 inhabitants. The methodology for the development of a Poly-SUMP (Figure 3) was developed within the framework of the European project "Polycentric Urban Mobility Plan (Poly-SUMP)," which was funded by the European Commission.

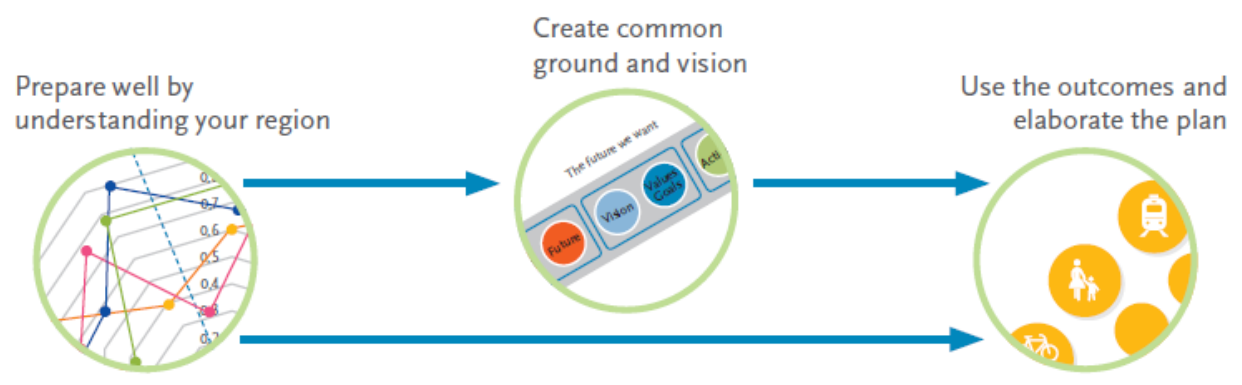

Figure 3. Poly-SUMP methodology (according to the Poly-SUMP Methodology, Guidelines, 2014).

\section{Results}

This section is divided by subheadings in order to provide a concise and precise description of the results and their interpretation linked with the specific methodological approach used in this paper, as well as the expert observations, which lead to clear conclusions, presented in the Section 4.

\subsection{Heritage Impact Assessment (HIA)}

According to UNESCO, the role of heritage in Environmental Impact Assessments (EIA) needs further elaboration as well as an emphasis on the linkages between nature and culture. Particularly, vulnerability to climate change and disaster risk also presents an important part of the impact assessment process. When it comes to climate change adaptation, just $32.72 \%$ of all of UNESCO's member states have some kind of mechanism in place related to the assessment of the vulnerability of urban areas' attributes to climate change. Project-based assessments are commonly used for evaluating the potential impacts of climate change [46].

On the other side, the most common model of impact assessment in which heritage is included is environmental assessments, involving $78.18 \%$ of member states, while heritage impact assessment (HIA) is presented by $69.09 \%$, and social impact assessments by $23.63 \%$ [46].

The special focus in this research paper is HIA for Boka Bay in Montenegro. 
3.1.1. HIA-Impact of Strategic Documents on the Exceptional Universal Value of the Natural and Cultural Heritage of Boka Bay

In the Management Plan of the Natural and Cultural-Historical Area of Kotor [50], a special chapter deals with factors and risks that in certain ways endanger the values of the protected area. All are cumulatively listed, and their influence on the attributes of exceptional universal value is not particularly explained, although among them there are those that are more significant precisely in terms of the possible negative impact on those attributes. In the management plan, the factors cumulatively listed can be grouped into certain groups that are characterized according to their basic orientation, i.e., according to the sector on which they have the most influence or in which certain possibilities of their remediation should be sought, i.e., remediation of their impact. These factors could be divided into the following groups: legislative issues and implementation of laws and bylaws, management issues and the problem of adequate staffing, planning and spatial planning issues, economic and infrastructural issues, conservation and museological issues, social issues, and environmental issues.

In the case of Kotor, most often, intangible factors (i.e., their impact) leave not only exceptional and significant material but also social, intangible consequences that are reflected not only in the objective reality of the physical environment of the protected area but also in the intangible sphere of traditional social relations, which have created spatial relations recognized and thus inscribed on the World List of Heritage.

Therefore, during the verification and implementation of the heritage impact assessment process, the material that was initially prepared for the Management Plan of the Natural and Cultural-Historical Area of Kotor is used as a useful and important basis for further consideration. In the management plan, the factors that are defined as a potential danger to the protected area are only cumulatively listed, while in this research paper, they are presented in problem groups with a comment adequate to the current circumstances for the better understanding of the main impacts on Boka Bay and presented in Table 1 in this section.

Table 1. Factors threatening values according to the management plan presented in HIA Boka Kotorska (source: authors, according to the HIA Boka Kotorska).

\begin{tabular}{|c|c|c|c|c|}
\hline Group of Factors & Group of Factors 1 & Group of Factors 2 & Group of Factors 3 & Group of Factors 4 \\
\hline $\begin{array}{l}\text { A group of factors } \\
\text { relating to } \\
\text { legislative issues and } \\
\text { law enforcement, and } \\
\text { by-laws }\end{array}$ & $\begin{array}{c}\text { Obsolescence and } \\
\text { inconsistency of the } \\
\text { Law on the Protection of } \\
\text { the Monumental Entity of } \\
\text { Kotor with the new Law } \\
\text { on the Protection of } \\
\text { Cultural Heritage and } \\
\text { other } \\
\text { systemic laws }\end{array}$ & $\begin{array}{l}\text { Lack of legal obligation to } \\
\text { prepare studies of visual } \\
\text { impact on natural and } \\
\text { cultural values of the } \\
\text { Kotor Area in the } \\
\text { process of } \\
\text { preparation of planning } \\
\text { and project } \\
\text { documentation }\end{array}$ & $\begin{array}{l}\text { Insufficient professional } \\
\text { and inspection } \\
\text { supervision to } \\
\text { prevent illegal } \\
\text { construction and works }\end{array}$ & $\begin{array}{l}\text { Non-compliance with } \\
\text { laws and bylaws }\end{array}$ \\
\hline $\begin{array}{c}\text { Management issues and } \\
\text { the problem } \\
\text { of adequate personnel } \\
\text { equipment }\end{array}$ & $\begin{array}{c}\text { Inadequate space } \\
\text { Management } \\
\text { Lack of a Managing } \\
\text { Authority in accordance } \\
\text { with UNESCO guidelines } \\
\text { (agencies, councils, etc.) } \\
\text { Inadequate monitoring of } \\
\text { all activities in the } \\
\text { protected area and contact } \\
\text { environment area } \\
\text { Insufficient coordination } \\
\text { between subjects in the } \\
\text { system of protection and } \\
\text { management }\end{array}$ & $\begin{array}{l}\text { Insufficient training of } \\
\text { professional profiles for } \\
\text { planning, design, and } \\
\text { execution of works for } \\
\text { areas with a high } \\
\text { concentration of cultural } \\
\text { assets }\end{array}$ & $\begin{array}{l}\text { Insufficient professional } \\
\text { capacities in the study, } \\
\text { protection, conservation, } \\
\text { and restoration of cultural } \\
\text { heritage } \\
\text { Insufficient professional } \\
\text { capacities for performing } \\
\text { works in traditional } \\
\text { techniques }\end{array}$ & $\begin{array}{c}\text { Lack of staff capacity, lack } \\
\text { of clear strategic staffing } \\
\text { policy and lack of } \\
\text { specialized educational } \\
\text { institutions for education } \\
\text { and training of staff in the } \\
\text { field of cultural heritage }\end{array}$ \\
\hline
\end{tabular}


Table 1. Cont.

\begin{tabular}{|c|c|c|c|c|}
\hline Group of Factors & Group of Factors 1 & Group of Factors 2 & Group of Factors 3 & Group of Factors 4 \\
\hline $\begin{array}{l}\text { Planning and spatial } \\
\text { planning issues }\end{array}$ & $\begin{array}{l}\text { Lack of Area Management } \\
\text { Plan } \\
\text { Obsolete urban planning } \\
\text { documents, especially } \\
\text { plans of the highest rank } \\
\text { for the coverage of the } \\
\text { Municipality of Kotor } \\
\text { (PPO and GUP), i.e., } \\
\text { failure to adopt the Spatial } \\
\text { Urban Plan of the } \\
\text { Municipality }\end{array}$ & $\begin{array}{c}\text { Discrepancy of } \\
\text { development concepts } \\
\text { with the spatial potentials } \\
\text { of the protected area and } \\
\text { the } \\
\text { restrictions set by the } \\
\text { protection criteria (large } \\
\text { tourist complexes, traffic } \\
\text { infrastructure, } \\
\text { infrastructure } \\
\text { technologies: plants, } \\
\text { stations, reservoirs, } \\
\text { warehouses) }\end{array}$ & $\begin{array}{c}\text { Inconsistency of standard } \\
\text { planning concepts of } \\
\text { inherited condition } \\
\text { improvement } \\
\text { heritage with prescribed } \\
\text { protection criteria and } \\
\text { principles of respect for } \\
\text { values } \\
\text { traditional architecture } \\
\text { Uncoordinated order of } \\
\text { preparation and adoption } \\
\text { of planning documents }\end{array}$ & \\
\hline $\begin{array}{c}\text { Economic and } \\
\text { infrastructure problems }\end{array}$ & $\begin{array}{l}\text { Lack of permanent sources } \\
\text { and a continuous way of } \\
\text { acquiring funds for the } \\
\text { protection and } \\
\text { improvement of the state } \\
\text { of cultural heritage } \\
\text { Non-collection of } \\
\text { associated communal } \\
\text { revenues based on the use } \\
\text { of natural and cultural } \\
\text { assets } \\
\text { Lack of accommodation - } \\
\text { hotel capacity }\end{array}$ & $\begin{array}{c}\text { Insufficient care and } \\
\text { maintenance of cultural } \\
\text { goods by owners and } \\
\text { users } \\
\text { Non - advancing incentive } \\
\text { measures for owners of } \\
\text { cultural property for } \\
\text { storage, maintenance and } \\
\text { implementation of } \\
\text { protection measures }\end{array}$ & $\begin{array}{c}\text { Insufficient and untimely } \\
\text { investment in } \\
\text { infrastructure } \\
\text { Insufficiently clear } \\
\text { strategic vision for the } \\
\text { development of tourism in } \\
\text { the protected area and } \\
\text { inadequate tourism } \\
\text { valorization of cultural } \\
\text { goods } \\
\text { Insufficient adaptation of } \\
\text { infrastructure for people } \\
\text { with disabilities }\end{array}$ & $\begin{array}{c}\text { The unsatisfactory } \\
\text { condition of traffic } \\
\text { infrastructure, insufficient } \\
\text { parking capacities space } \\
\text { and insufficient use of } \\
\text { water for regular transport } \\
\text { of local population and } \\
\text { tourists in the Bay of } \\
\text { Kotor and Risan }\end{array}$ \\
\hline \multirow[t]{3}{*}{$\begin{array}{l}\text { Conservation and } \\
\text { museological problems }\end{array}$} & $\begin{array}{c}\text { Insufficient research, } \\
\text { professional valorization } \\
\text { of space, lack of protection } \\
\text { studies } \\
\text { cultural assets for all } \\
\text { settlements of the area, as } \\
\text { well as the undefined } \\
\text { protected environment of } \\
\text { the Area }\end{array}$ & $\begin{array}{l}\text { Illegal and unprofessional } \\
\text { works on cultural goods } \\
\text { and non-compliance with } \\
\text { the principles of } \\
\text { protection }\end{array}$ & $\begin{array}{c}\text { Failure to implement } \\
\text { normative and } \\
\text { documentary protection of } \\
\text { movable, immovable and } \\
\text { intangible cultural } \\
\text { heritage, prescribed by } \\
\text { law }\end{array}$ & $\begin{array}{c}\text { Lack of space for storage, } \\
\text { protection, and } \\
\text { presentation of movable } \\
\text { cultural property, } \\
\text { especially archaeological } \\
\text { finds in the Kotor area }\end{array}$ \\
\hline & $\begin{array}{l}\text { Lack of study of the } \\
\text { cultural landscape of the } \\
\text { area and the Bay of Kotor }\end{array}$ & $\begin{array}{l}\text { Inadequate physical } \\
\text { protection of cultural } \\
\text { property on land and } \\
\text { underwater } \\
\text { consequently } \\
\text { in particular, there is the } \\
\text { illegal extraction of } \\
\text { archaeological objects } \\
\text { from the seabed }\end{array}$ & & $\begin{array}{c}\text { Inadequate museum } \\
\text { spaces and depots for safe } \\
\text { storage of museum objects } \\
\text { and } \\
\text { their protection from theft, } \\
\text { vandalism, fire, and other } \\
\text { harmful influences that } \\
\text { may occur } \\
\text { anticipate, as well as the } \\
\text { untimely and inadequate } \\
\text { implementation of } \\
\text { conservation treatment of } \\
\text { the museum material }\end{array}$ \\
\hline & $\begin{array}{l}\text { Inadequate conditions for } \\
\text { the preservation of wall } \\
\text { paintings, iconostasis, and } \\
\text { paintings on canvas and } \\
\text { wood in the interior of the } \\
\text { church }\end{array}$ & & & \\
\hline
\end{tabular}


Table 1. Cont.

\begin{tabular}{|c|c|c|c|c|}
\hline Group of Factors & Group of Factors 1 & Group of Factors 2 & Group of Factors 3 & Group of Factors 4 \\
\hline Social problems & $\begin{array}{l}\text { Insufficiently developed } \\
\text { awareness of the values } \\
\text { and potentials of space }\end{array}$ & $\begin{array}{c}\text { Insufficient and } \\
\text { inadequate education of } \\
\text { the society, } \\
\text { especially the school } \\
\text { population about the } \\
\text { values and potentials of } \\
\text { the } \\
\text { protected area }\end{array}$ & $\begin{array}{l}\text { Population migration } \\
\text { caused by real estate sales }\end{array}$ & Lack of professional staff \\
\hline & $\begin{array}{l}\text { Insufficient level of } \\
\text { awareness of the } \\
\text { population about the } \\
\text { values of the protected } \\
\text { area as } \\
\text { development potentials }\end{array}$ & & & Extinction of old crafts \\
\hline \multirow[t]{3}{*}{ Environmental problems } & $\begin{array}{l}\text { Uncontrolled exploitation } \\
\text { of plant species, which } \\
\text { destroys the habitats of } \\
\text { many species, } \\
\text { the appearance of the } \\
\text { landscape and the living } \\
\text { conditions of plants and } \\
\text { animals are changing }\end{array}$ & $\begin{array}{l}\text { Unprofessional and illegal } \\
\text { works, related to the filling } \\
\text { and expansion of natural } \\
\text { beaches and the coastline } \\
\text { with artificial stone and } \\
\text { the reconstruction of the } \\
\text { bridge with concrete and } \\
\text { other modern materials, } \\
\text { which destroy the } \\
\text { ecosystems of the coastal } \\
\text { sea }\end{array}$ & $\begin{array}{l}\text { Illegal discharge of } \\
\text { sewage into the sea }\end{array}$ & $\begin{array}{c}\text { Filling of rubble and other } \\
\text { construction waste into } \\
\text { the sea }\end{array}$ \\
\hline & \multirow[t]{2}{*}{ Overfishing } & & $\begin{array}{l}\text { Insufficient discharge } \\
\text { control from large ships } \\
\text { and cruisers }\end{array}$ & \multirow[t]{2}{*}{$\begin{array}{l}\text { Uncontrolled construction } \\
\text { in the coastal part }\end{array}$} \\
\hline & & & $\begin{array}{l}\text { Lack of a special ship for } \\
\text { cleaning the sea surface }\end{array}$ & \\
\hline
\end{tabular}

The initial (umbrella) document in accordance with which the regional concept of tourism development for the Bay of Kotor was made is the Montenegro Tourism Development Strategy to 2020 [51], in which Boka is recognized as a highly attractive cultural-historical and landscape unique in the Mediterranean, which due to unplanned construction is in extreme danger of losing these characteristics. In addition, the fact that the Bay of Kotor is one of the most beautiful bays in the world is emphasized in this master plan and that the preservation of the city of Kotor as a world cultural heritage is in the "pan-European" interest.

As one of the key shortcomings of the Bay of Kotor for the development of tourism, the master plan recognizes the limited capacity for swimming tourism, which is the most economically important market segment everywhere in the world. Special limitations (weak points) stand out: lack of quality (acceptable beaches), poor water quality in the bay due to inadequate wastewater treatment, as well as the main road directly along the coast with a high frequency of passenger and freight traffic.

For Montenegro, the preservation of ecological values is determined by the Constitution, thus legally prescribing the obligation to achieve the protection of the environment and identity in practice, not only when development measures are taken but also when they eliminate disorders originating from the past. This is especially true for the Bay of Kotor, where, due to many interventions directly in the bay, intensive tourist use is not possible for now. At the same time, such a situation reduces the economic effects of those projects that could be implemented in certain locations.

Economic revitalization of the hinterland in order to extend the season, with the parallel formation of the network of pedestrian and bicycle paths, which should connect the Austro-Hungarian fortifications and mountain villages, could be driven by the activation of the archeological research and conservation of revitalization of heritage sites along these routes. 
Among the users of the space, cyclists and pedestrians are especially recognized, which can be crucial in the process of developing sustainable urban mobility in order to develop cultural tourism by connecting archeological sites in the Bay of Kotor.

\subsubsection{HIA-Urban Mobility and Plan for Construction of the New Bridge "Verige" in Boka Bay}

In the introductory chapter of the Statement of Outstanding Universal Values of Bay of Kotor, it is stated that it is the strait of Verige, and the whole view of the strait (which Risan and Kotor Bay connects with the rest of the Bay of Kotor) is one of the key visual accents in the whole spatial assembly. It is the position and characteristics of the strait and its narrowest part, canal Verige (Figure 4), one of the key attributes of exceptional universal value, which characterizes the list of world-heritage-inscribed goods. In this area, the views are focused as you approach that part of the bay that is defined as the most significant but also where the views open to the exit to the rest of the bay and ultimately toward the open sea from the most valuable historical settlements (especially Perast and its surroundings) that characterize the building substrate of the protected area. The property is linked to the rest of the Boka Kotorska Bay through a narrow channel forming the principal visual central axis of the area [52].

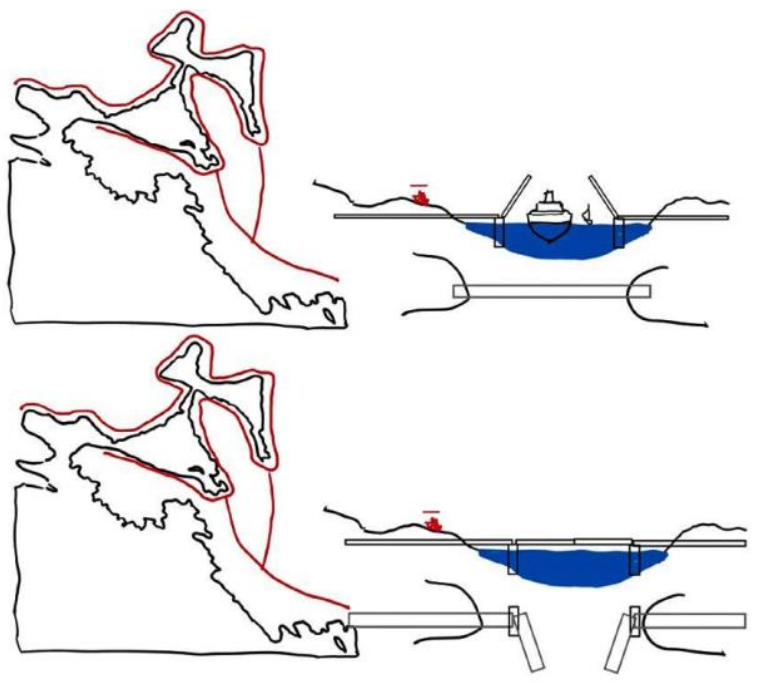

Figure 4. Scheme of the presentation of movable structures of bridges that ensure the possibility of passage of large ships-vertical and horizontal (source: Adapted from "Heritage Impact Assessment for the Natural and Cultural-Historical Area of Kotor-Plan to Build a Bridge at the Verige Site" [52]).

\subsection{Sustainable Urban Mobility as a Driver of Heritage Protection and Management and Healthy Environment}

The polycentric sustainable urban mobility plan (Poly-SUMP) [4] for Boka Bay and Cetinje faced the many challenges related to the integration of innovative modern technologies while trying on the one hand to respect the protection of UNESCO's Kotor and on the other hand to provide for the everyday needs of inhabitants and tourists.

A Poly-SUMP defines the way in which the plans, priorities, and programs of the users, concerning the transformation of the transport system, lead to changes over time and affect a number of different policy objectives. A Poly-SUMP will make it easier to reach a transportation system accessible to all, connecting communities by improving access to jobs and services, offering access to all residents and visitors, making the main touristic locations, including archeological sites, more accessible. Using of the Poly-SUMP tool in the urban regeneration process could contribute to improving the attractiveness and quality of the urban environment in local centers and the key transport corridors, and on the other side, it will decrease energy consumption and reduce GHG emissions, with emphasis on the tourism sector. That is why integrated urban planning could directly contribute to urban 
regeneration through Poly-SUMP tool usage for a healthier environment and sustainable urban development.

Under the proposed 24 measures presented in the Poly-SUMP for Boka Bay, divided into five categories, under the category "Construction of new and reconstruction of the existing transport infrastructure," one of eight proposed measures is "Reconstruction of the old Austro-Hungarian road/Revival of cultural monuments in the hinterland" [4] (p. 44). This is an important urban mobility measure that could contribute to the activation of the archeological and urban heritage sites for its further sustainable usage in the process of urban regeneration.

Boka Bay has relatively favorable natural and physical conditions for the development of different modes of transport, with the aim to integrate these in the wider environment and transportation network (Figure 5), linking efficiently the region to further destinations. The analysis undertaken under the SUMP project report concluded that there are indeed significant opportunities for the Boka Bay area in terms of sustainable urban transport development, which, however in their majority are not yet in a mature phase. Furthermore, it is evident from the strategies of the municipalities examined that there is still room for better integration concerning their goals and plans for future investments in the urban environment. The identified low-carbon transport options for the region are mainly infrastructure related and aim at providing better transport services within the area [4] (p. 56).

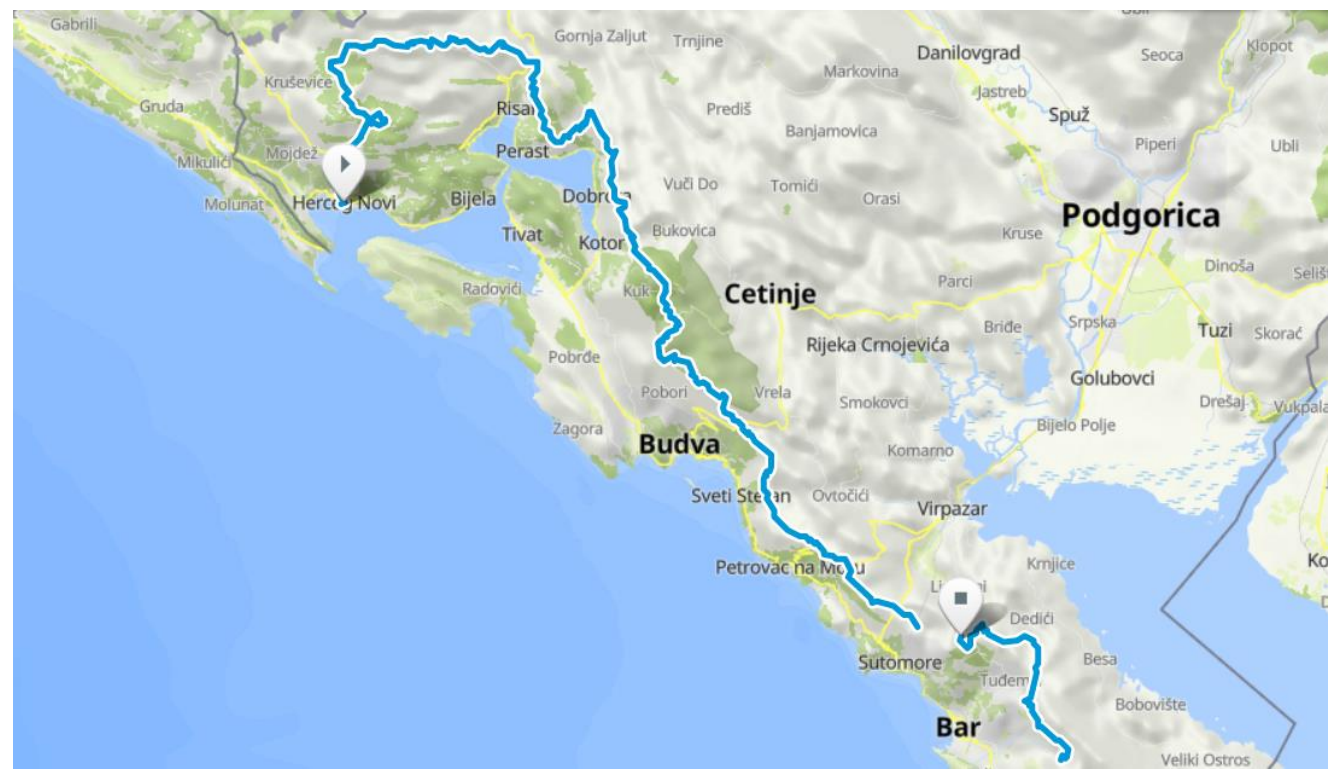

Figure 5. Coastal-mountain transversal Orjen-Lovcen-Rumija (source: Mountaineering Association of Montenegro).

Cultural monuments in the hinterland represent a true revelation for tourists and hikers, and their access roads consist of attractive hiking tracks. Their multiple values have not been properly recognized, with the exception of a few cases (Herceg Novi used a part of its architectural heritage by revitalizing Forta Mare, Kanli Kula). The greatest value of these monuments around the Boka Bay area is their origin and the fact that most of them are still in fairly good condition. Therefore, the archeological sites in Boka have an outstanding potential for tourism increase. Unfortunately, the old access roads are usually in poor condition, which is one of the main obstacles to exploiting the touristic potential of these sites. The proposed measure mainly refers to improving and enhancing the existing network of the old Austro-Hungarian roads, thus making accessible these cultural and historical sites. It is noted that given the large number of monuments scattered around the area, it is necessary to prioritize the locations according to the local plans, with the ultimate 
aim of reviving the cultural and historical heritage and increasing the attractiveness of the entire area [4] (p. 165).

These mostly unused Austro-Hungarian transport corridors are mainly linked with the archeological sites in the Boka Bay region, and for the purpose of understanding their value and role in the urban regeneration process, the archeological sites belonging to four historic periods are mapped for the first time through cartographical presentation in this paper (Figures 6 and 7).
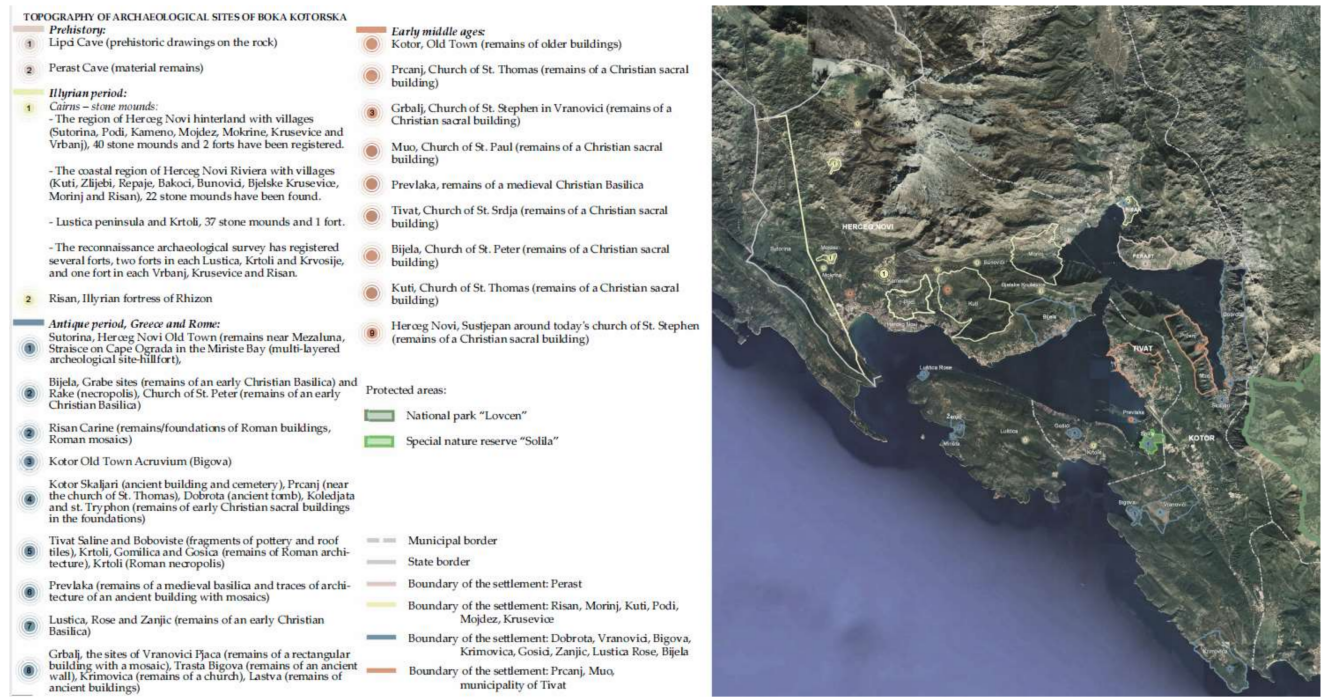

Figure 6. Topography of the archeological sites of Boka Kotorska presented in groups according to the historical period (prepared by the author S. Lazarević).

Analyses of the archeological sites according to type and the existing situation must be planned accordingly. The authors' site observation contributed to the preparation of a map of archeological sites divided into four historical periods, prehistory, the Illyrian period, the Antique period, and the Early Middle Ages (Table 2 and Figures 6 and 7), identifying these as archeological sites most in danger of being totally destroyed as these sites are mainly just stone mounds and other remains. In this article, the heritage sites from the Middle Ages are not analyzed and presented because of the huge number of different kinds of heritage sites, which implies different criteria of analyzing.

For the purpose of further scientific research of the archeological sites belonging to these four huge historical periods, all sites identified by the authors through literature and desk research and expert site observation are presented divided by city location so other researchers can easily find the locations of these important archeological sites (Figures 8-12). These maps will also be of significant importance in the process of developing cultural heritage management plans.

For the purpose of a clear and concise presentation of the archeological sites, the role of which in the process of urban regeneration could be further discussed, all archeological sites are listed in the historical period along with the current Boka Bay cities' boundaries (Figures 8-12). This kind of methodological approach of analyzing these sites is important for their easier assessment through HIA and their timely involvement in urban mobility plans in the process of urban regeneration, which we confirmed through this research could contribute to the sustainable urban development process taking into consideration the role of archeological sites in all of these processes. 


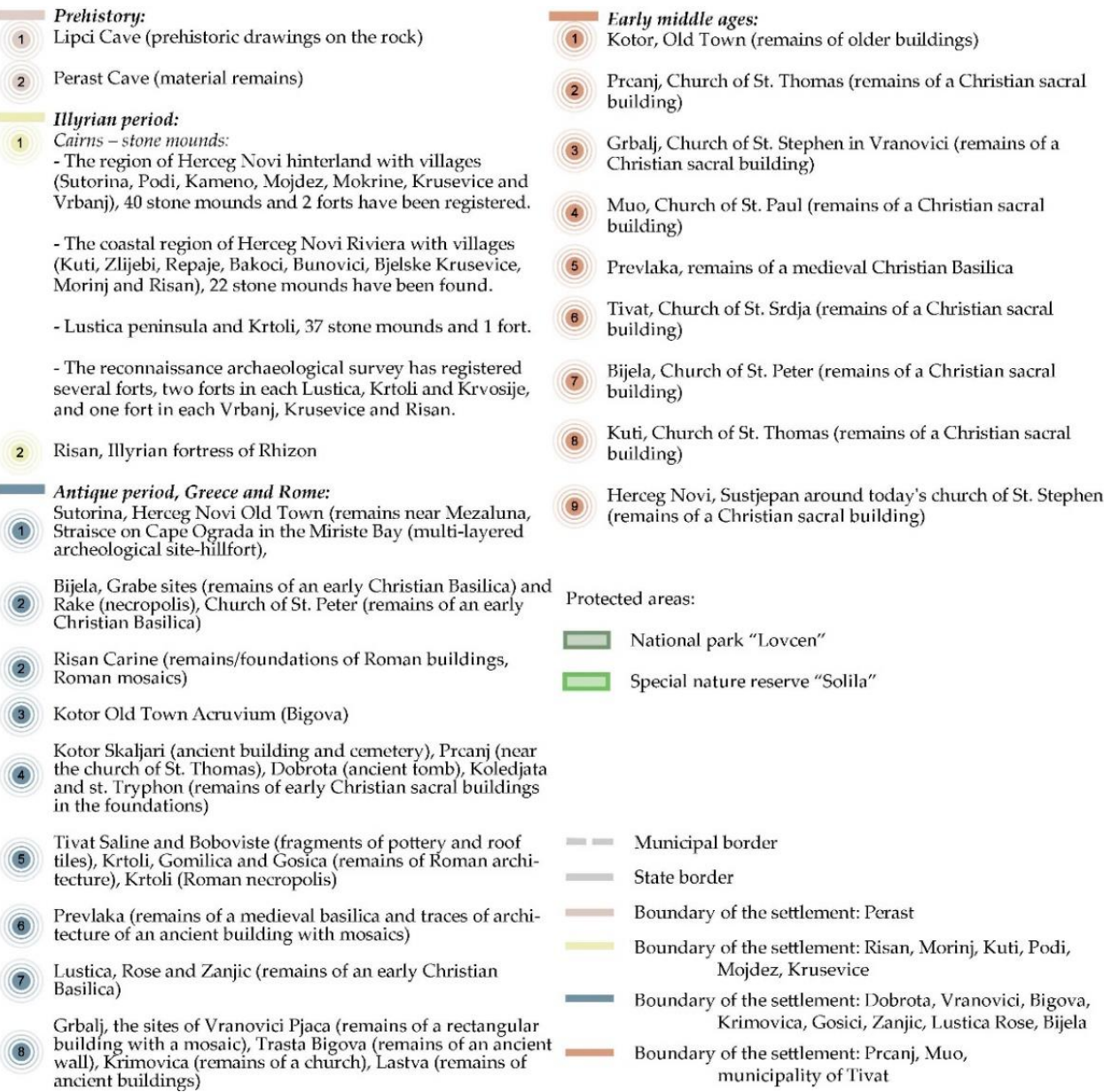

Figure 7. List of mapped archeological sites of Boka Kotorska presented in groups according to the historical period (prepared by the author S. Lazarević).

Table 2. Analyses of the archeological sites according to type (prepared by the author S. Lazarević).

\begin{tabular}{|c|c|c|c|c|c|c|c|c|}
\hline \multirow[b]{2}{*}{$\begin{array}{c}\text { City/ } \\
\text { Type of Sites }\end{array}$} & \multicolumn{8}{|c|}{ Number of the Archaeological Sites per Its Existing Situation/Sort } \\
\hline & $\begin{array}{l}\text { Total no. of } \\
\text { Sites per } \\
\text { Periods }\end{array}$ & $\begin{array}{l}\text { Drawings } \\
\text { and } \\
\text { Mosaics }\end{array}$ & $\begin{array}{l}\text { Material } \\
\text { Remains }\end{array}$ & $\begin{array}{l}\text { Forts -Stone } \\
\text { Mounds }\end{array}$ & Fortress & $\begin{array}{l}\text { Necropolis } \\
\text { and Sacral } \\
\text { Buildings }\end{array}$ & $\begin{array}{c}\text { Fortified } \\
\text { Towns }\end{array}$ & $\begin{array}{c}\text { Multi-Layered } \\
\text { Archaeological } \\
\text { Site }\end{array}$ \\
\hline \multicolumn{9}{|c|}{ RISAN } \\
\hline Prehistory & $\mathbf{x}$ & $\mathrm{x}$ & $\mathrm{x}$ & $\mathrm{x}$ & $\mathrm{x}$ & $\mathrm{x}$ & $\mathrm{x}$ & $\mathrm{x}$ \\
\hline Illyrian period & 2 & $\mathrm{x}$ & $\mathrm{x}$ & 1 & 1 & $\mathrm{x}$ & $\mathrm{x}$ & $\mathrm{x}$ \\
\hline $\begin{array}{l}\text { Antique } \\
\text { period }\end{array}$ & 2 & 1 & 1 & $\mathrm{x}$ & $\mathrm{x}$ & $\mathrm{x}$ & $\mathrm{x}$ & $\mathrm{x}$ \\
\hline $\begin{array}{c}\text { Early Middle } \\
\text { Ages }\end{array}$ & $\mathbf{x}$ & $\mathrm{x}$ & $x$ & $x$ & $\mathrm{x}$ & $\mathrm{x}$ & $\mathrm{x}$ & $x$ \\
\hline \multicolumn{9}{|c|}{ PERAST } \\
\hline Prehistory & 2 & $x$ & 2 & $x$ & $x$ & $x$ & $x$ & $x$ \\
\hline Illyrian period & $x$ & $\mathrm{x}$ & $x$ & $x$ & $x$ & $x$ & $x$ & $x$ \\
\hline $\begin{array}{l}\text { Antique } \\
\text { period }\end{array}$ & $\mathrm{x}$ & $\mathrm{x}$ & $\mathrm{x}$ & $\mathrm{x}$ & $\mathrm{x}$ & $\mathrm{x}$ & $x$ & $\mathrm{x}$ \\
\hline $\begin{array}{l}\text { Early Middle } \\
\text { Ages }\end{array}$ & $x$ & $x$ & $x$ & $\mathrm{x}$ & $\mathrm{x}$ & $\mathrm{x}$ & $\mathrm{x}$ & $\mathrm{x}$ \\
\hline
\end{tabular}


Table 2. Cont.

\begin{tabular}{|c|c|c|c|c|c|c|c|c|}
\hline \multirow[b]{2}{*}{$\begin{array}{c}\text { City/ } \\
\text { Type of Sites }\end{array}$} & \multicolumn{8}{|c|}{ Number of the Archaeological Sites per Its Existing Situation/Sort } \\
\hline & $\begin{array}{l}\text { Total no. of } \\
\text { Sites per } \\
\text { Periods }\end{array}$ & $\begin{array}{l}\text { Drawings } \\
\text { and } \\
\text { Mosaics }\end{array}$ & $\begin{array}{l}\text { Material } \\
\text { Remains }\end{array}$ & $\begin{array}{l}\text { Forts -Stone } \\
\text { Mounds }\end{array}$ & Fortress & $\begin{array}{l}\text { Necropolis } \\
\text { and Sacral } \\
\text { Buildings }\end{array}$ & $\begin{array}{l}\text { Fortified } \\
\text { Towns }\end{array}$ & $\begin{array}{c}\text { Multi-Layered } \\
\text { Archaeological } \\
\text { Site }\end{array}$ \\
\hline \multicolumn{9}{|c|}{ KOTOR } \\
\hline Prehistory & 2 & $\mathrm{x}$ & 2 & $\mathrm{x}$ & $\mathrm{x}$ & $\mathrm{x}$ & $\mathrm{x}$ & $\mathrm{x}$ \\
\hline Illyrian period & 4 & $\mathrm{x}$ & 1 & 3 & $\mathrm{x}$ & $\mathrm{x}$ & $\mathrm{x}$ & $\mathrm{x}$ \\
\hline $\begin{array}{l}\text { Antique } \\
\text { period }\end{array}$ & 9 & $\mathrm{x}$ & 2 & $\mathrm{x}$ & $\mathrm{x}$ & 5 & 1 & 1 \\
\hline $\begin{array}{l}\text { Early Middle } \\
\text { Ages }\end{array}$ & 4 & $\mathrm{x}$ & $\mathrm{x}$ & $\mathrm{x}$ & $\mathrm{x}$ & 3 & 1 & $\mathrm{x}$ \\
\hline \multicolumn{9}{|c|}{ TIVAT } \\
\hline Prehistory & $\mathbf{x}$ & $\mathrm{x}$ & $\mathrm{x}$ & $\mathrm{x}$ & $\mathrm{x}$ & $x$ & $\mathrm{x}$ & $\mathrm{x}$ \\
\hline Illyrian period & 3 & $\mathrm{x}$ & 1 & 2 & $\mathrm{x}$ & $x$ & $\mathrm{x}$ & $\mathrm{x}$ \\
\hline $\begin{array}{l}\text { Antique } \\
\text { period }\end{array}$ & 41 & $\mathrm{x}$ & 37 & $\mathrm{x}$ & $\mathrm{x}$ & 3 & $\mathrm{x}$ & 1 \\
\hline $\begin{array}{l}\text { Early Middle } \\
\text { Ages }\end{array}$ & 1 & $\mathrm{x}$ & $\mathrm{x}$ & $\mathrm{x}$ & $\mathrm{x}$ & 1 & $\mathrm{x}$ & $\mathrm{x}$ \\
\hline \multicolumn{9}{|c|}{ HERCEG NOVI } \\
\hline Prehistory & $\mathbf{x}$ & $\mathrm{x}$ & $\mathrm{x}$ & $x$ & $x$ & $\mathrm{x}$ & $\mathrm{x}$ & $\mathrm{x}$ \\
\hline Illyrian period & 68 & $\mathrm{x}$ & 62 & 6 & $\mathrm{x}$ & $\mathrm{x}$ & $\mathrm{x}$ & $\mathrm{x}$ \\
\hline $\begin{array}{l}\text { Antique } \\
\text { period }\end{array}$ & 7 & $\mathrm{x}$ & 1 & $\mathrm{x}$ & $\mathrm{x}$ & 3 & $\mathrm{x}$ & 3 \\
\hline $\begin{array}{l}\text { Early Middle } \\
\text { Ages }\end{array}$ & 3 & $\mathrm{x}$ & $\mathrm{x}$ & $\mathrm{x}$ & $\mathrm{x}$ & 3 & $\mathrm{x}$ & $\mathrm{x}$ \\
\hline
\end{tabular}

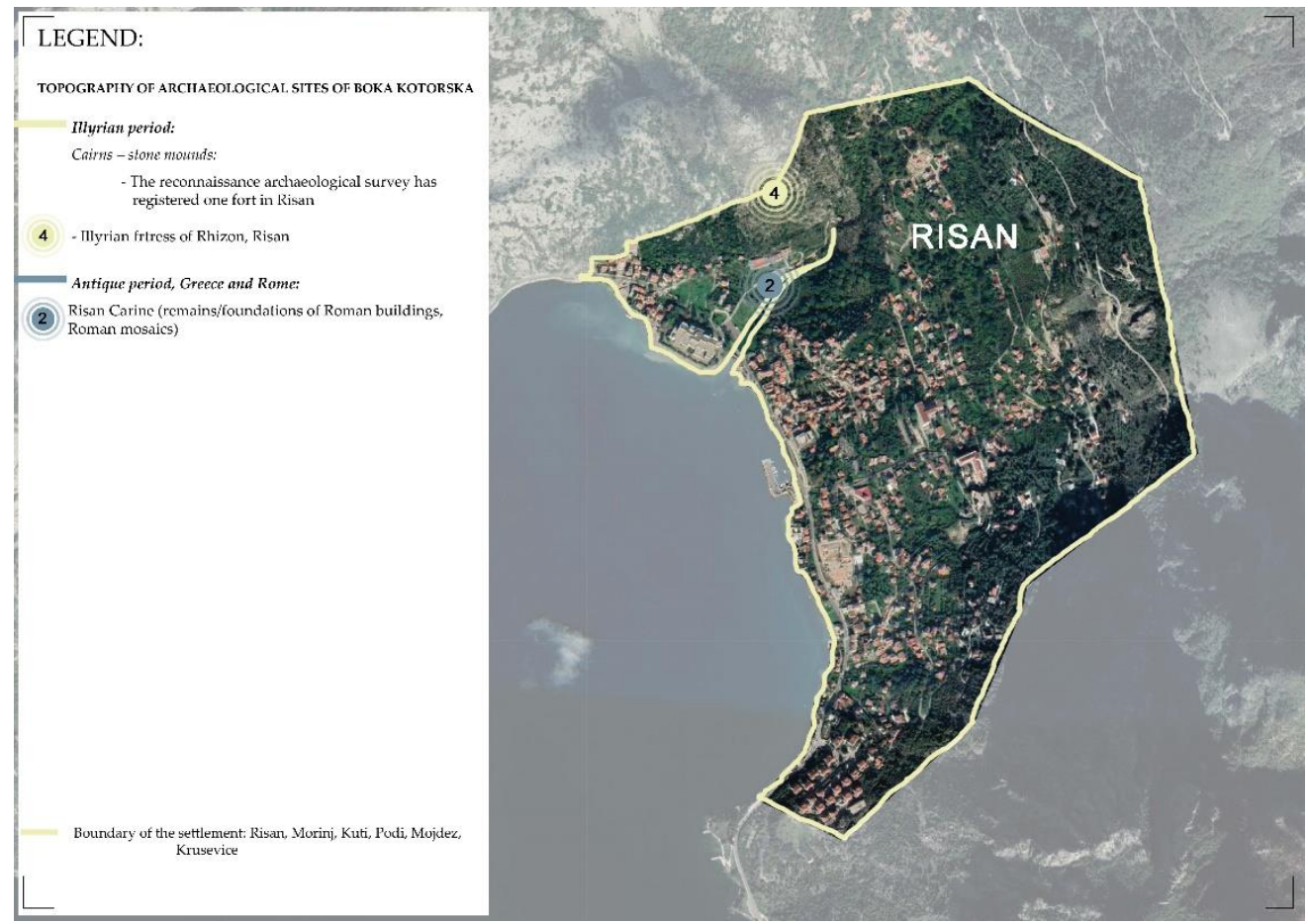

Figure 8. Topography of the archeological sites of Risan presented in groups according to the historical period (prepared by the author S. Lazarević). 


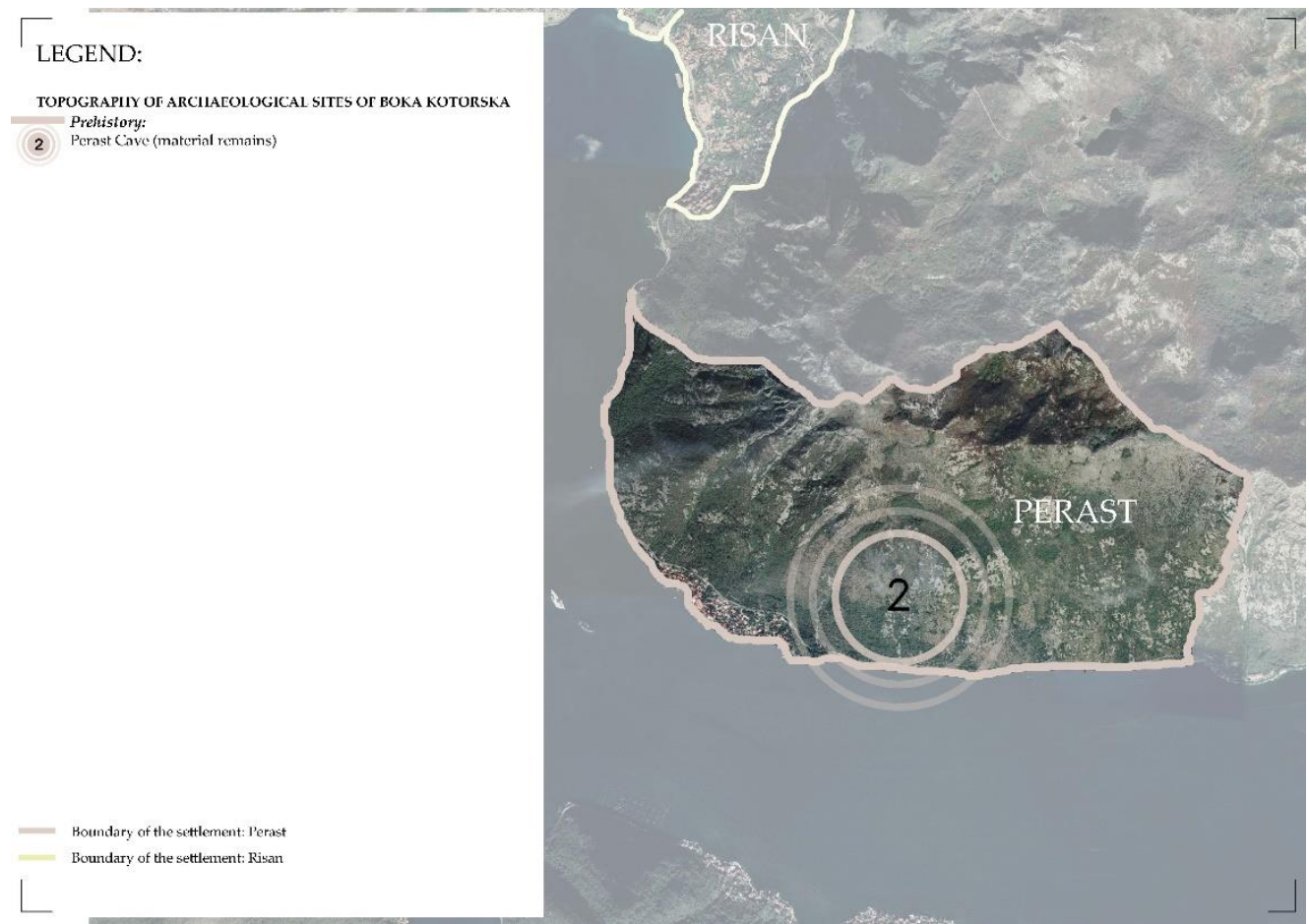

Figure 9. Topography of the archeological sites of Perast presented in groups according to the historical period (prepared by the author S. Lazarević).

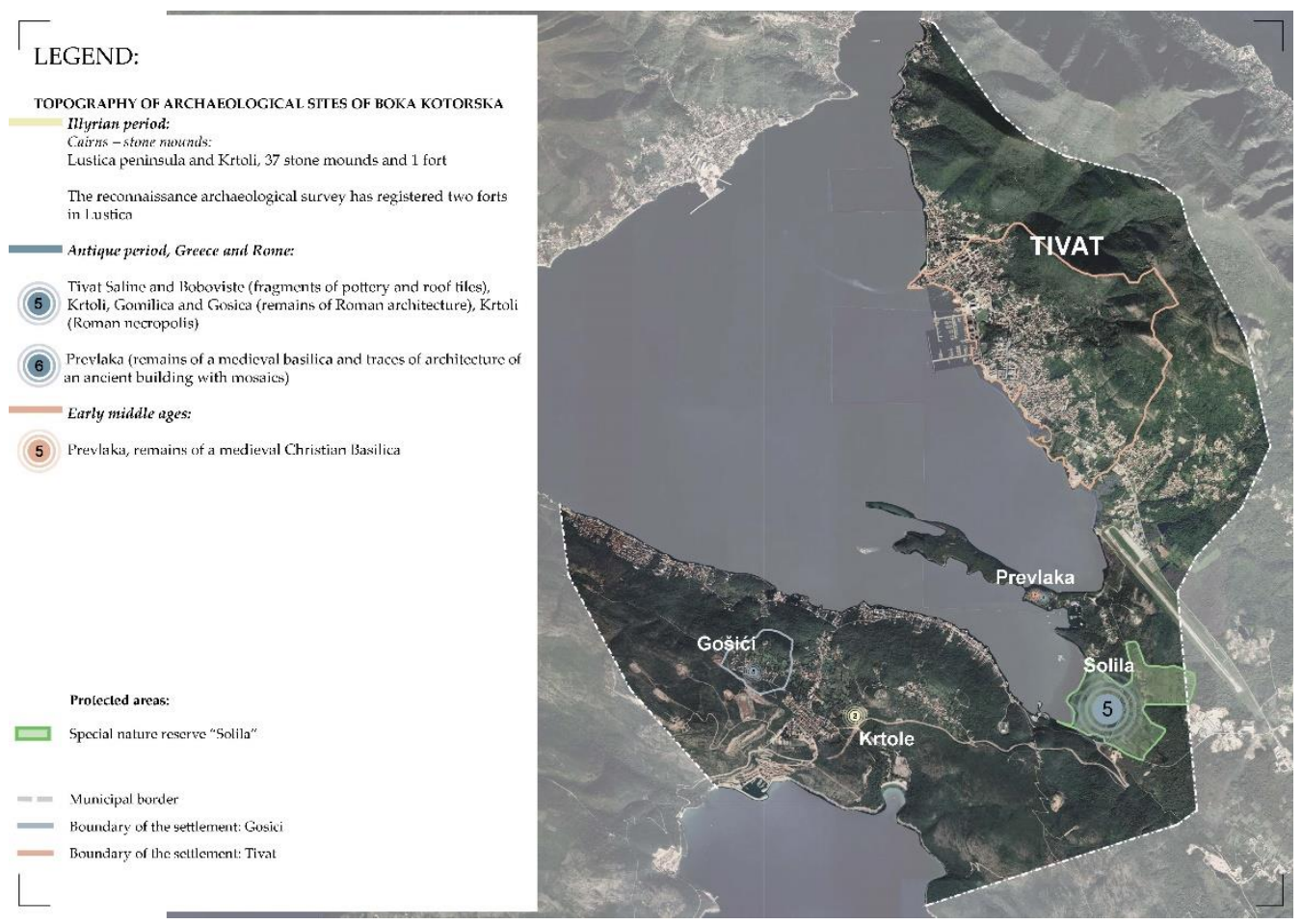

Figure 10. Topography of the archeological sites of Tivat presented in groups according to the historical period (prepared by the author S. Lazarević). 


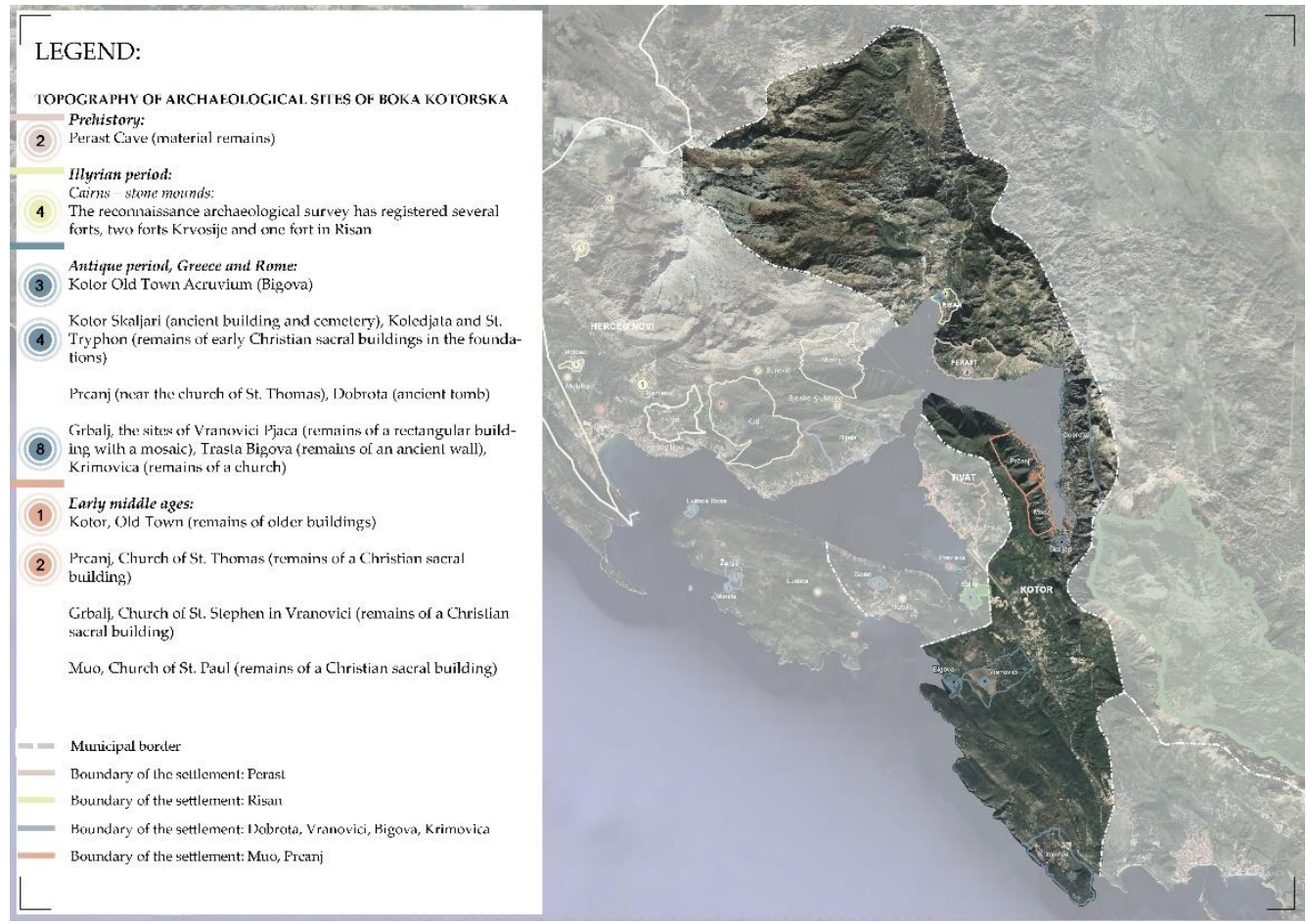

Figure 11. Topography of the archeological sites of Kotor presented in groups according to the historical period (prepared by the author S. Lazarević).

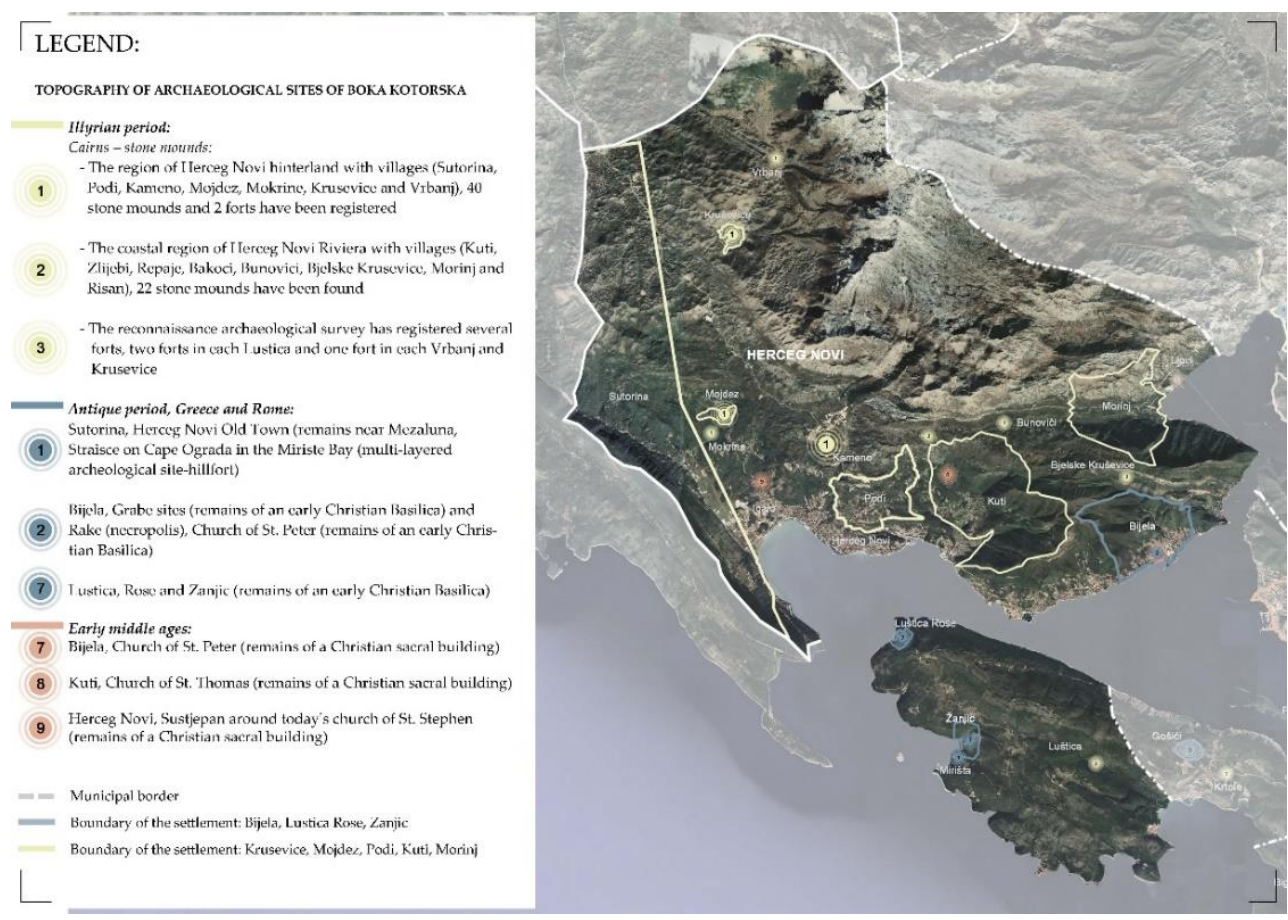

Figure 12. Topography of the archeological sites of Herceg Novi presented in groups according to the historical period (prepared by the author S. Lazarević).

\section{Discussion and Conclusions}

What is concluded from the analysis of the content of the theory of new urbanism and the concept of urban regeneration is that although it is said that the existing urban centers and cities as coherent metropolitan areas should be revitalized and that it is important to 
care for the conservation and protection of our built heritage, including archeological and cultural heritage sites, the integration of these approaches into practice is insufficient.

The results of developed heritage impact assessments and the sustainable urban mobility plan for Boka Bay confirm the necessity of better integration of these processes as part of urban regeneration that could help both in the protection and sustainable management of archeological cultural heritage and its further sustainable integration into the strategy for sustainable archeology, with the aim of protection of both the natural and the cultural environment. Landscapes surrounding archeological heritage sites in Boka Bay play a special role in these processes. Thus, heritage sites need to be assessed more deeply before any spatial planning interventions.

In this paper, all mapped archeological sites are presented with their most probable locations as per expert site research and observation and their names according to the historical review and available literature. The results of this research, even if extremely important for the theory of history and anthropology, as well as archeological knowledge considering the number and importance of the archeological sites, have caused concern, given that no archeological research has been done on these sites so far and thus they are not included in the most important strategic plans for the development of the Bay of Kotor, which entails the impossibility of preparing management plans for these valuable sites. In the process of the urban regeneration of UNESCO's cities, there is no huge number of authors or research papers that give concrete solutions for the integration of the archeological sites in this process even if it is obvious and clear after this analysis that a role of archeological sites in the urban regeneration process from the aspects of all three pillars of sustainability, economic, social, and environmental, is of significant importance.

Adequate protection and treatment of archeological and architectural heritage sites are a necessary precondition for the implementation of the concept of sustainable urban regeneration, and especially for their connection with urban cores. Thus, urban mobility and connection with archeological sites outside the urban center need special focus in further urban regeneration of UNESCO's sites taking into account the fact that these sites have to be preserved not just for the sake of their outstanding value but for the reason of their integration into new master urban plans as a resource that clearly contributes to a healthier built environment and thus contributes to the sustainable management of the archeology.

The results of this study show that practical usage of the two proposed tools in the process of urban regeneration could help in cultural and natural heritage protection and their inclusion as drivers of sustainable urban planning and cultural heritage management. The results of the study confirm the authors' hypothesis that the role of the archeological sites in the process of urban regeneration is evident in the touristic cities in the coastal area of Montenegro, concluding that the urban mobility principles and heritage impact assessment studies must be considered in the process of urban regeneration while at the same time the cultural (archeological) heritage management is an integral part of this process.

Author Contributions: Conceptualization, S.L., D.A. and S.G.P.; methodology, S.L.; validation, D.A. and S.G.P.; formal analysis, S.L.; resources, S.L., D.A. and S.G.P.; writing-original draft preparation, S.L.; writing - review and editing, S.L., D.A. and S.G.P.; visualization, S.L. and D.A.; supervision, S.L. and S.G.P. All authors have read and agreed to the published version of the manuscript.

Funding: This research was partially funded by the Faculty of Architecture in Podgorica through work on HIA studies for which the Ministry of Culture of Montenegro provided funds in 2017 years, while the Poly-SUMP Boka Bay study is funded through the GEF's (Global Environmental Fund) project "Toward Carbon Neutral Tourism," which was implemented by UNDP Montenegro (20152020). Article is funded by the Zagreb University of Applied Sciences, Vrbik 8, 10000, Zagreb, Croatia.

Institutional Review Board Statement: Not applicable.

Informed Consent Statement: Not applicable. 


\section{Data Availability Statement: Not applicable.}

Conflicts of Interest: The authors declare no conflict of interest. The funders had no role in the design of the study; in the collection, analyses, or interpretation of data; in the writing of the manuscript; or in the decision to publish the results.

\section{References}

1. Willems, W.J.H. Archaeological resource management and preservation. In Preserving Archaeological Remains In Situ, Proceedings of the 3rd Conference Geoarchaeological and Bioarchaeological Studies, Amsterdam, The Netherlands, 7-9 December 2006; Kars, H., Heeringen, R.M., Eds.; Institute for Geo- and Bioarchaeology: Amsterdam, The Netherlands, 2006; pp. 283-289.

2. Willems, W.J.H. Uncovering Quality Gold. QW 2008, 34, 40-41.

3. Amado, M.; Rodrigues, E. A Heritage-Based Method to Urban Regeneration in Developing Countries: The Case Study of Luanda. Sustainability 2019, 11, 4105. [CrossRef]

4. Popovic, M.; Tselenti, N.; Lazarevic, S. Polycentric Sustainable Urban Mobility Plan for Boka Bay and the Old Royal Capital of Cetinje: BokaCet 2020; UNDP Montenegro: Podgorica, Montenegro, 2017; p. 14.

5. The Rulebook on Detailed Criteria and Procedure for Determining Cultural Values of Goods recognizes the following criteria: Authenticity, integrity, degree of preservation, uniqueness and rarity within their species, historical, artistic, scientific, archaeological, architectural, anthropological, technical or other significance. In Official Gazette of Montenegro; Constitutional Assembly of the Republic of Montenegro: Podgorica, Montenegro, 2011; p. 18.

6. Zakon o zaštiti kulturnih dobara. In Official Gazette of Montenegro no. 049/10 from 13.08.2010, 040/11 from 08.08.2011, 044/17 from 06.07.2017, 018/19 from 22.03.2019l; Constitutional Assembly of the Republic of Montenegro: Podgorica, Montenegro, 2019.

7. Council of Europe. European Cultural Convention. Paris, 19.XII. 1954. Available online: https://rm.coe.int/168006457e (accessed on 10 December 2021).

8. Council of Europe. The European Landscape Convention. Florence. 2000. Available online: https://www.coe.int/en/web/ landscape (accessed on 10 December 2021).

9. Renfrew, C.; Bahn, P.G. Archaeology: Theories, Methods and Practice; Thames \& Hudson: London, UK, $2008 ;$ p. 50.

10. Willems, W.J.H. Archaeological Resource Management and Academic Archaeology in Europe: Some Observations. In Quale Futuro per Lárcheologia; D’Agata, A.L., Alaura, S., Eds.; Dipartimento Patrimonio Culturale, Consigno Nazionale delle Ricerche: Roma, Italy, 2009; p. 94.

11. Egloff, B.; Comer, D.C. Conserving the Archaeological Soul of Places: Drafting guidelines for the ICAHM Charter. In Proceedings of the 16th ICOMOS General Assembly and International Symposium: "Finding the Spirit of Place-Between the Tangible and the Intangible", Quebec City, QC, Canada, 29 September-4 October 2008; ICOMOS: Quebec City, Canada, 2008 ; pp. 1-12.

12. Willems, W.J.H. Archaeological heritage management and research. In Quo Vadis Archaeologia? Whither European Archaeology in the 21st Century? Proceedings of the European Science Foundation Exploratory Workshop, Madralin near Warsaw, Poland, 12-13 October 2001; Kobylinski, Z., Ed.; European Science Foundation/Institute of Archaeology and Ethnology of the Polish Academy of Sciences/Foundation "Res Publica Multietnica": Warsaw, Poland, 2001; p. 86.

13. Carman, J. Archaeology \& Heritage. An Introduction; Continuum: London, UK, 2000; pp. 303-308.

14. UNESCO. Convention Concerning the Protection of the World Cultural and Natural Heritage. 1972. Available online: https: //whc.unesco.org/en/conventiontext/ (accessed on 10 December 2021).

15. Mijušković, S. Novo Tumačenje Jednog Fragmenta iz “Tabula Peutingeriana”. Istor. Zapisi 1966, 23, 111-129.

16. Pušič, I. Preistorijski Crteži na Stijeni u Lipcima, Godišnjak IV; Balkan Research Center in Sarajevo: Sarajevo, Bosnia and Herzegovina, 1966.

17. Pušič, I. Novi Pravac Rimske Ceste Kroz Boku Kotorsku. Istor. Zapisi 1975, 32, 127-131.

18. Varga, V. Podmorski Arheološki Lokaliteti Njivice—rt Uvala Ribarice; Muzejske Sveske Zavičajnog Muzeja u Herceg Novom: Herceg Novi, Montenegro, 1998; pp. 29-30.

19. Martinović, J. Ranohrišćanska Krstionica Ispod Crkve Sv. Marije od Rijeke u Kotoru; Prilozi Povijesti Umjetnosti u Dalmaciji: Split, Croatia, 1990; Volume 29, pp. 22-31.

20. Garašanin, M. Crna Gora u praistorijsko doba. In Istorija Crne Gore—od Najstarijih Vremena do Kraja XII Vijeka, Knj. I; Redakcija za Istoriju Crne Gore: Titograd, Montenegro, 1967.

21. Mijović, P. Acruvium-Decatera-Kotor u Svijetlu Novih Arheoloških Otkrića. Starinar 1962-1963, 43-44, 13-14.

22. Mijović, P.; Kovačević, M. Gradovi i Utorđenja u Crnoj Gori; Arheološki Institut: Beograd, Serbia; Muzej Ulcinj: Ulcinj, Montenegro, 1975.

23. Mijović, P. Urbani Razvoj Crne Gore u Anticko Doba-Buthua-Olcinium-Bar; Obod: Cetinje, Montenegro, 1975.

24. Bošković, Đ. Osvrt na Neke Zamke Koje Očekuju Istraživača Prilikom Identifi-Kovanja Konstrukcija Predantičkog i Antičkog Doba. In Proceedings of the Conference: Materijali, Tehnike i Strukture Predantičkog i Antičkog Graditeljstva na Istočnom Jadranskom Prostoru, Zadar, Croatia, 6-8 December 1976.

25. Jovanović, А. Римске Некрополе на Територији Југославије; Univerzitet u Beogradu: Belgrade, Serbia, 1984.

26. Čubrović, Z. Ка Познавању Үрбанистичког Развоја Пераста; Бока 23, Gradska Biblioteka i Čitaonica: Herceg Novi, Montenegro, 2003. 
27. Lisavac, К. Палата Змајевић у Перасту; Бока 23, Gradska Biblioteka i Čitaonica: Herceg Novi, Montenegro, 2003.

28. Ilijanić, B. Zbornik Radova BOKA; Gradska Biblioteka i Čitaonica: Herceg Novi, Montenegro, 2009.

29. Ilijanić, B. Urbana Geneza-Rektifikacija Starih Planova Herceg Novi-Stari Grad, Crna Gora, Istočna Obala Jadranskog Mora. Istraživački Rezime; Ilibo Design Architects: Herceg Novi, Montenegro, 1998.

30. Ilijanić, B. Resinum Romanum-Herceg Novi; Ilibo Design Architects: Herceg Novi, Montenegro, 2018-2019.

31. Lalošević, I. Фортичикацаони Системи Пераста. God. Pomor-Skog Muz. Kotor 1995-1998, 43-44.

32. Lalošević, I. Obnova i Zaštita Istorijskih Građevina Područja Kotora Nakon Zemljotresa 1979. Godine; Boka 34; Zbornik Radova Iz nauke, Kulture i Umjetnosti; Gradska Biblioteka i Čitaonica: Herceg Novi, Montenegro, 2014.

33. Lalošević, I. Utvrđeni Punktovi Kotorske Torđave Venecijanskog Perioda; Boka 40; Zbornik Radova iz Nauke, Kulture i Umjetnosti; Gradska Biblioteka i Čitaonica: Herceg Novi, Montenegro, 2010.

34. Cleere, H. World cultural resource management: Problems and perspectives. In Approaches to the Archaeological Heritage; Cleere, H., Ed.; Cambridge University Press: Cambridge, UK, 1984; p. 125.

35. Willems, W.J.H. Archaeology and Heritage Management in Europe: Trends and Developments. EJA 1998, 1, 295. [CrossRef]

36. Pedregal, P.D.; Diekmann, A. How to Reconcile Archeological Site Protection and Visitor Accessibility? Getty Publications: Los Angeles, CA, USA, 2012; p. 773. ISBN 978-1-60606-124-4.

37. Nicolau, A.; Nicolau, M. Interpretation and Display. In Urban Pasts and Urban Futures: Bringing Urban Archaeology to LifeEnhancing Urban Archaeological Remains, International and Interdisciplinary Symposium; EU Committee of the Regions: Brusseles, Belgium, 2005; p. 31

38. Begović, B. Ekonomika Urbanističkog Planiranja; Centar za Ekonomske Studije: Beograd, Serbia, 1995; p. 348.

39. Moughtin, C. Urban Design: Street and Square, Routledge; Taylor \& Francis Group: Abingdon-on-Thames, UK, 2003; ISBN 9780750657174.

40. Vaništa-Lazarević, E. Obnova Gradova u Novom Milenijumu; Classic Map Studio: Beograd, Serbia, 2003.

41. Bazik, D. Iniciranje regeneracije javnih gradskih prostora. In Urbani Dizajn; Bogdanović, R., Ed.; Društvo Urbanista Beograda: Beograd, Serbia, 2006; pp. 259-272.

42. Serraino, M.; Lucchi, E. Energy Efficiency, Heritage Conservation, and Landscape Integration: The Case Study of the San Martino Castle in Parella (Turin, Itlay). Energy Procedia 2017, 11, 4483. [CrossRef]

43. Amado, M. How to Transform Today's City; Caleidoscopio-Edição e Artes Gráficas S.A.: Lisbon, Portugal, 2019.

44. United Nations. Transforming Our World: The 2030 Agenda for Sustainable Development. Available online: https://sdgs.un. org/2030agenda (accessed on 7 November 2021)

45. United Nations. Habitat III, New Urban Agenda. Available online: http://habitat3.org/wp-content/uploads/New-UrbanAgenda-GA-Adopted-68th-Plenary-N1646655-E.pdf (accessed on 7 November 2021).

46. UNESCO. Recommendation on the Historic Urban Landscape. Available online: https://whc.unesco.org/en/hul/ (accessed on 7 November 2021).

47. Nicholson, C. Mobility 2030: Meeting the Challenges to Sustainability: The Sustainable Mobility Project; Full Report 2004; World Business Council for Sustainable Development: Conches, Geneva, 2004.

48. SUMP: Sustainable Urban Mobility Plan-European Platform on Sustainable Urban Mobility Plan-ELTIS. Available online: www.eltis.org/mobility-plans (accessed on 15 May 2021).

49. Poly-SUMP: Policentric Sustainable Urban Mobility Plan-Planning Sustainable Mobility Together. Available online: http: / / www.poly-sump.eu/ (accessed on 15 May 2021).

50. Ministry of Culture of Montenegro. Menadžment Plan Prirodnog i Kulturno-Istorijskog Područja Kotora; Ministry of Culture of Montenegro: Cetinje, Montenegro, 2011.

51. Ministry of Ecology, Spatial Planning and Urbanism. Montenegro Tourism Development Strategy to 2020; Ministry of Ecology, Spatial Planning and Urbanism: Podgorica, Montenegro, 2011.

52. Arbutina, D.; Popović, G.S. Heritage Impact Assessment for the Natural and Cultural-Historical Area of Kotor-Plan to Build a Bridge at the Verige Site; Architectural faculty of University of Montenegro: Podgorica, Montenegro, 2017. 